University of Nebraska - Lincoln

DigitalCommons@University of Nebraska - Lincoln

7-2015

\title{
Short-term Response of Holcus lanatus L. (Common Velvetgrass) to Chemical and Manual Control at Yosemite National Park, USA
}

Laura J. Jones

Steven M. Ostoja

Matthew L. Brooks

Martin Hutten

Follow this and additional works at: https://digitalcommons.unl.edu/usgsstaffpub

Part of the Geology Commons, Oceanography and Atmospheric Sciences and Meteorology Commons, Other Earth Sciences Commons, and the Other Environmental Sciences Commons

This Article is brought to you for free and open access by the US Geological Survey at DigitalCommons@University of Nebraska - Lincoln. It has been accepted for inclusion in USGS Staff -- Published Research by an authorized administrator of DigitalCommons@University of Nebraska - Lincoln. 


\title{
Short-term Response of Holcus lanatus L. (Common Velvetgrass) to Chemical and Manual Control at Yosemite National Park, USA
}

\author{
Laura J. Jones, Steven M. Ostoja, Matthew L. Brooks, and Martin Hutten*
}

\begin{abstract}
One of the highest priority invasive species at both Yosemite and Sequoia and Kings Canyon national parks is Holcus lanatus L. (common velvetgrass), a perennial bunchgrass that invades mid-elevation montane meadows. Despite velvetgrass being a high priority species, there is little information available on control techniques. The goal of this project was to evaluate the short-term response of a single application of common chemical and manual velvetgrass control techniques. The study was conducted at three montane sites in Yosemite National Park. Glyphosate spotspray treatments were applied at $0.5,1.0,1.5$, and $2.0 \%$ concentrations, and compared with hand pulling to evaluate effects on cover of common velvetgrass, cover of other plant species, and community species richness. Posttreatment year 1 cover of common velvetgrass was $12.1 \% \pm 1.6$ in control plots, $6.3 \% \pm 1.5$ averaged over the four chemical treatments (all chemical treatments performed similarly), and 13.6\% \pm 1.7 for handpulled plots. This represents an approximately 50\% reduction in common velvetgrass cover in chemically- treated plots recoded posttreatment year 1 and no statistically significant reduction in hand pulled plots compared with controls. However, there was no treatment effect in posttreatment year 2, and all herbicide application rates performed similarly. In addition, there were no significant treatment effects on nontarget species or species richness. These results suggest that for this level of infestation and habitat type, (1) one year of hand pulling is not an effective control method and (2) glyphosate provides some level of control in the short-term without impact to nontarget plant species, but the effect is temporary as a single year of glyphosate treatment is ineffective over a twoyear period.
\end{abstract}

Nomenclature: Glyphosate; common velvetgrass, Holcus lanatus L.

Key words: Hand pulling, invasive species, Sierra Nevada, meadow, Yosemite National Park.

Yosemite (YOSE) and Sequoia and Kings Canyon (SEKI) national parks have made major progress with most high priority invasive species during the past few decades [e.g., yellow starthistle (Centaurea solstitialis L.), Himalayan blackberry (Rubus armeniacus Focke), and bull thistle (Cirsium vulgare L.)]. However, there has been less

\section{DOI: $10.1614 /$ IPSM-D-14-00060.1}

* First author: Ecologist, National Park Service, Yosemite National Park, Division of Resources Management and Science, 5230 Foresta Road, El Portal, CA 95318; second author: Supervisory Ecosystems Staff Officer, US Forest Service, Sierra National Forest, Clovis, CA 93611; third author: Supervisory Research Ecologist, US Geological Survey, Western Ecological Research Center, Yosemite Field Station, Oakhurst, CA 93644; fourth author: Biologist, US Forest Service, Wrangell Ranger District, Tongass National Forest, Wrangell, AK 99929. Corresponding author's E-mail: stevenmostoja@fs.fed.us success with Holcus lanatus L. (common velvetgrass). Concern over common velvetgrass is due to its apparent ability to alter montane meadows, which are among the most highly valued natural resources in the region due to their ecosystem biodiversity (Debinski et al. 2000; Graber 1996; Kattelmann and Embury 1996), wilderness, and recreational values. Common velvetgrass can form locally dense stands that have the potential to alter moisture availability, ecosystem function and habitat quality, and to displace native species (Bastow et al. 2008).

Common velvetgrass has been documented as a problem on park lands over a wide geographic range, from Haleakala National Park on Maui (Anderson et al. 1992; Loope et al. 1992) to Yellowstone National Park (http:// www.invasive.org/weedus/park.html) and across a great elevation range within the California floristic province from sea level at Point Reyes National Seashore (Bobbi 


\section{Management Implications}

This study was designed to evaluate short-term effects of a single application of chemical and mechanical control techniques on Holcus lanatus L. (common velvetgrass) cover and nontarget plant cover and species richness. Our results showed that various glyphosate concentrations were equally effective at reducing cover of common velvetgrass, and that there were no statistically significant effects of treatments on nontarget cover and species richness. A one-time spot spray application was effective at reducing common velvetgrass in the post-treatment year 1 , but not longer. These spot-spray herbicide treatments, even at the highest concentrations, did not have detrimental effects on nontarget species. This is particularly important where land management objectives are not just to control invasive plant infestations but also to support native species, special status plants, or traditionally used plants (i.e., plants species that are important in ongoing American Indian traditional cultural practices such as those involving ceremony, subsistence and artistry). Despite the lack of herbicide impacts to nontarget species at any of the concentrations evaluated, the lowest concentration $(0.5 \%)$ would be recommended because higher concentrations were no more effective at controlling velvetgrass. Despite the statistically significant reduction in common velvetgrass cover during posttreatment year $1,6.3 \%$ common velvetgrass cover still remained, and the reduced cover effect was gone by posttreatment year 2 . This study suggests that glyphosate treatments could be an option to control common velvetgrass, but one application will not maintain control after the first year. In order to gain long-term control, managers could experiment with glyphosate treatments repeated annually or even multiple times per year to control infestations. Hand pulling common velvetgrass at these densities for only one year was ineffective at controlling common velvetgrass. Moreover, studies have suggested that repeated hand pulling of velvetgrass and the associated soil disturbance could promote local increases in nonnative species.

Simpson, personal communication) to the montane Sierra Nevada at SEKI (A. Demetry, personal communication).

Early Yosemite naturalists noted common velvetgrass as an invader of Yosemite Valley's montane meadows (Michael 1929; Naramore 1949). This species has now established dense local populations in mid-elevation mesic (e.g., Yosemite Valley, 1,200 m [4,000 ft] meadows of YOSE [Klinger et al. 2006; Underwood et al. 2004] and is estimated to occupy approximately 122 ha [300 gross infested acres] within the park [National Park Service 2014]). Although higher elevation meadows (above $1,800 \mathrm{~m}[6,000 \mathrm{ft}]$ ) are generally less invaded than other ecosystems in the Sierra Nevada (D'Antonio et al. 2004), common velvetgrass was recently discovered at 2,200 m $(7,260 \mathrm{ft})$ elevation in Yosemite (G. Dickman, personal communication).

In 2010 the YOSE Invasive Plant Management Plan (IPMP) established prioritization and treatment of invasive species as among the programmatic priorities within the division of resource management and science (National
Park Service 2010). Common velvetgrass is among the species identified as high priority in the 2010 IPMP which rated it as medium ecosystem impact, high ecological threat, and estimated moderate difficulty to control based on its life history characteristics of prolific seeding, vegetative spread from decumbent tillers, high growth rates, and ability to persist perennially even under grazing pressure. The 2014 Invasive Plant Work Plan emphasized treatment of species that are ranked as high priority (National Park Service 2014). Additionally, common velvetgrass is also ranked as a species of moderate concern at the statewide level by the California Invasive Plant Council (Cal-IPC 2006).

We are unaware of any published report for control of common velvetgrass specifically, although limited information suggests mixed success using various methods. A reduction in spread can be achieved by mowing or grazing if timed before seed set (Bakker et al. 1980), although low-intensity grazing has also been shown to facilitate spread (Thompson and Turkington 1988), and common velvetgrass can regenerate from remaining underground biomass (Watt and Haggar 1980). Land stewards have suggested that hand pulling is effective, although time consuming (NatureServe 2013). In YOSE and SEKI, small patches have been encountered and successfully removed through persistent hand pulling of small patches and of scattered plants intermixed with native species, where velvetgrass is not the dominant vegetation (A. Demetry and G. Dickman, personal commmunication). However, this approach has proven completely ineffective in larger-scale removal projects (G. Dickman, personal communication.) and is infeasible at the scale of infestation in YOSE and SEKI. Because common velvetgrass may persist in the seed bank for up to ten years, repeated control may be required (M. Hutton, personal communication).

The goal of invasive plant management in YOSE and SEKI is not just to remove non-natives, but to also enhance the dominance of native plant species. Accordingly, an important objective of control efforts for common velvetgrass is to also minimize potential negative effects on nontarget native species. In general, few herbicide efficacy studies report on the outcome of nontarget plants and results of those studies report both positive effects and negative outcomes (e.g., Laufenberg et al. 2005; Måren et al. 2008; Rice and Toney 1998; Rice et al. 1997; Tyser et al. 1998). However, graminoid-specific herbicides have been shown to reduce damage to a dominant native plant compared with the nonspecific glyphosate (Milligan et al. 2003). However, selective herbicides that could chemically target common velvetgrass were not authorized for use in YOSE (National Park Service 2010). An additional constraint is that the IPMP environmental assessment prohibits spraying herbicide over standing water which 
limits the seasonal timing options for treatment because the populations of greatest concern occur in seasonally flooded wetland habitats.

Common velvetgrass generally invades and occupies localized regions within meadows rather than being widespread throughout the meadow unit. This localized distribution pattern increases the likelihood of success of control efforts. However, the current lack of knowledge on short and longer-term outcomes of control techniques limits the extent to which appropriate management options can be identified. Additionally, the ultimate goal of invasive plant control activities is to not only control the target species (e.g., common velvetgrass), but to maintain or restore conditions favorable to the dominance and diversity of native species. The objectives of this project were to evaluate the short-term effects of a single application of chemical and mechanical control techniques on: (1) common velvetgrass plant cover, (2) nontarget plant cover; and (3) community species richness.

\section{Material and Methods}

Study Site. This study took place within and adjacent to three meadow study sites within YOSE. Mean (plot) pretreatment common velvetgrass cover averaged over all sites ranged between 2.1 and $57.7 \%$. Stoneman Meadow in Yosemite Valley directly north of Curry Village $\left(37^{\circ} 44^{\prime} 29.24^{\prime \prime} \mathrm{N}, 119^{\circ} 34^{\prime} 16.67^{\prime \prime} \mathrm{W} ; 1210 \mathrm{~m}[3,990 \mathrm{ft}]\right.$ elevation) is characterized as meadow-mixed oak/evergreen forest ecotone that burned seven years prior to sampling. The mean (plot) initial common velvetgrass cover was $14.5 \% \pm 1.4$, and representative species in the local plant community included; Blue wildrye (Elymus glaucus Buckley), Kentucky bluegrass (Poa pratensis L.), Bristly dogstail grass (Cynosurus echinatus L.), Slenderbeak sedge (Carex athrostachya Olney) and fragile sheathed sedge (Carex fracta Mack.). The Big Meadow site, located off Big Oak Flat Road $\left(37^{\circ} 42^{\prime} 11.11^{\prime \prime} \mathrm{N}, 119^{\circ} 44^{\prime} 7.50^{\prime \prime} \mathrm{W} ; 1,326 \mathrm{~m}[4,375\right.$ $\mathrm{ft}$ ] elevation), is a riparian meadow and lacked any tree canopy cover and burned one year prior to the first year of sampling. Initial common velvetgrass cover at the Big Meadow site was $22.8 \% \pm 2.1$ and representative species in the local plant community included; field horsetail (Equisetum arvense L.), Western brackenfern [Pteridium aquilinum (L.) Kuhn)] Yosemite sedge (Carex sartwelliana Olney), oxeye daisy (Leucanthemum vulgare Lam.) and willowherb (Epilobium spp.). The Soupbowl site, located $0.85 \mathrm{~km}(0.5 \mathrm{mi})$ from the Wawona Meadow and $0.15 \mathrm{~km}$ $(0.1 \mathrm{mi})$ from Wawona Road $\left(37^{\circ} 31^{\prime} 41.01^{\prime \prime} \mathrm{N}\right.$, $119^{\circ} 37^{\prime} 38.50^{\prime \prime} \mathrm{W} ; 1,377 \mathrm{~m}$ [4,540 ft] elevation) is a moist seep in open-forest understory that burned five years prior to sampling. Initial common velvetgrass cover at the Soupbowl site was $13.4 \% \pm 1.3$ and representative species in the local plant community included: streambank bird's-foot trefoil [Lotus oblongifolius (Benth.) Greene], Yosemite sedge, Kentucky bluegrass, mountain rush (Juncus arcticus Willd.) and American bird's-foot trefoil [Acmispon americanus (Nutt.) Rydb.]. These sites were selected because they are the few areas in YOSE with adequate common velvetgrass densities to conduct the experiment with adequate replication to meet the experiments objectives.

Experimental Design. At each study site 48 treatment plots were established each measuring $4 \mathrm{~m}^{2}$. Each of six treatments was randomly applied to eight replicate treatment plots between June 22 and 29, 2010, when common velvetgrass was in boot stage. Treatments included: (1) untreated control; (2) glyphosate diluted with water to $0.5 \%$ volume to volume (v/v); (3) glyphosate $1.0 \% \mathrm{v} / \mathrm{v}$; (4) glyphosate $1.5 \% \mathrm{v} / \mathrm{v}$; (5) glyphosate $2.0 \%$ v/v; and (6) hand pulling. Agri-dex ${ }^{\circledR}$ (Helena Chemical Company, 225 Shilling Boulevard, Collierville, TN 38017) was used as a surfactant for all herbicide treatments because it is approved for wetland use in California. Herbicides were applied by spot spraying from a backpack sprayer each common velvetgrass plant in the treatment plots. Hand pulling was accomplished by removing all above-ground biomass and as much of the root system as possible of each velvetgrass plant by hand without the use of tools.

Sampling Design. Ocular percent cover within each treatment plot was measured for common velvetgrass within each of two $1 \mathrm{~m}^{2}$ subplots, and then averaged to create a single value for each treatment plot. Ocular percent cover for all nontarget species combined was measured within one of the two common velvetgrass subplots. Species richness was measured by tallying the total number of species within the single nontarget species subplot, resulting in an estimate at the $1 \mathrm{~m}^{2}$ scale. Sampling was performed in June 2010 immediately prior to treatment application to establish a pretreatment baseline, then again in June 2011 and 2012 to evaluate posttreatment year 1 and 2 responses.

Data Analyses. Repeated measures multivariate analysis of variance MANOVA was used to evaluate the three response variables of common velvetgrass cover, nontarget species cover, and species richness across the main effects of year $(n=3$; pretreatment year, posttreatment year 1 , posttreatment year 2$)$, site $(n=3)$, and treatment $(n=$ 6 ) and their respective two-way and three-way interactions. Count (richness) data were square root transformed and the arcsine transformation was use for proportional data (cover) to better meet normality assumptions for statistical comparisons. In all cases back-transformed data are presented in figures. All analyses are considered statistically 
Table 1. Repeated measures multivariate analysis of variance results for (A) Common velvetgrass cover, (B) Nontarget species cover, and (C) Species richness.

\begin{tabular}{|c|c|c|c|}
\hline \multicolumn{4}{|c|}{ (A) Common velvetgrass cover } \\
\hline Source & $\mathrm{DF}$ & F Ratio & Prob $>F$ \\
\hline Site & 2,125 & 11.12 & $<0.001$ \\
\hline Year & 2,124 & 50.89 & $<0.001$ \\
\hline Treatment & 5,125 & 0.93 & 0.4637 \\
\hline Site $\times$ treatment & 10,125 & 1.40 & 0.1871 \\
\hline Site $\times$ year & 2,125 & 9.40 & $<0.001$ \\
\hline Year $\times$ treatment & 5,125 & 4.85 & $<0.001$ \\
\hline Site $\times$ year $\times$ treatment & 10,125 & 1.44 & 0.1705 \\
\hline \multicolumn{4}{|l|}{ (B) Nontarget cover } \\
\hline Source & $\mathrm{DF}$ & F Ratio & P Value \\
\hline Site & 2,125 & 8.96 & $<0.001$ \\
\hline Year & 2,124 & 36.69 & $<0.001$ \\
\hline Treatment & 5,125 & 1.76 & 0.127 \\
\hline Site $\times$ treatment & 10,125 & 0.97 & 0.471 \\
\hline Site $\times$ year & 2,125 & 7.45 & $<0.001$ \\
\hline Year $\times$ treatment & 5,125 & 2.96 & 0.015 \\
\hline Site $\times$ year $\times$ treatment & 10,125 & 1.32 & 0.228 \\
\hline \multicolumn{4}{|l|}{ (C) Species richness } \\
\hline Source & $\mathrm{DF}$ & F Ratio & P Value \\
\hline Site & 2,125 & 79.48 & $<0.001$ \\
\hline Year & 2,124 & 55.76 & $<0.001$ \\
\hline Treatment & 5,125 & 1.970 & 0.086 \\
\hline Site $\times$ treatment & 10,125 & 1.13 & 0.341 \\
\hline Site $\times$ year & 2,125 & 55.76 & $<0.001$ \\
\hline Year $\times$ treatment & 5,125 & 1.79 & 0.121 \\
\hline Site $\times$ year $\times$ treatment & 10,125 & 1.69 & 0.089 \\
\hline
\end{tabular}

significant at $\alpha \leq 0.05$, and all statistical analyses where done using JMP 8.01 (SAS institute 2008).

\section{Results and Discussion}

Common Velvetgrass Cover Response to Treatments. Although the main effect of treatments on common velvetgrass cover was not significant (Table 1A), there was a notable effect of herbicides during posttreatment year 1 (but not year 2) as indicated by a significant year by treatment interaction (Table 1A). Posttreatment year 1 common velvetgrass cover averaged $6.3 \% \pm 1.5$ for the four chemical treatments combined, about half of the $12.1 \% \pm 1.6$ cover recorded for the control plots. There was no obvious difference in effectiveness among the four herbicide treatments during posttreatment year 1 as all application rates similarly reduced velvetgrass cover relative to the control plots during that year (Figure 1A). Hand pulling treatments were similar to control plots during both posttreatment years 1 and 2 .
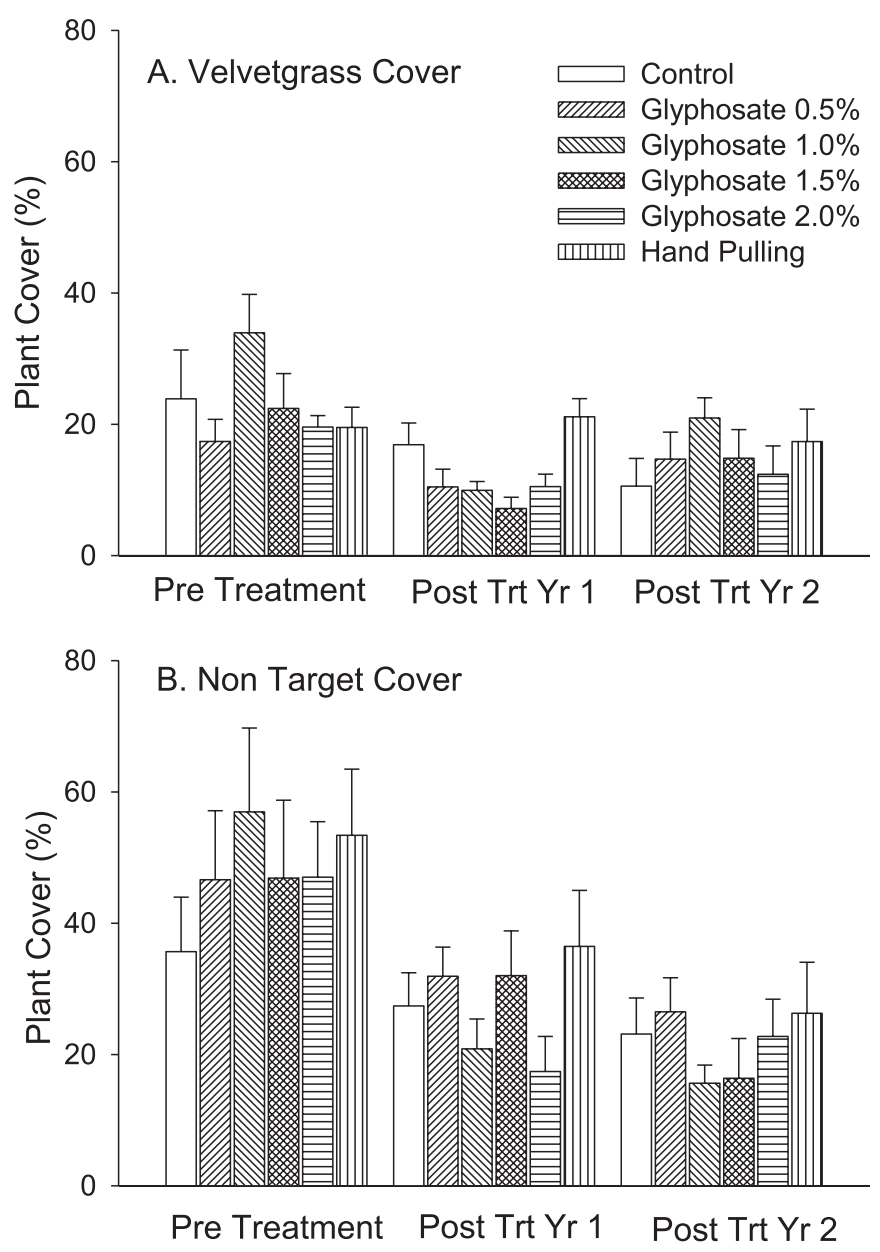

Figure 1. A. Mean common velvetgrass percent cover ( \pm SE) and $B$. mean nontarget species percent cover $( \pm S E)$ at the $1 \mathrm{~m}^{2}$ scale for each of the six treatments for 2010 (pretreatment), 2011 (posttreatment year 1) and 2012 (posttreatment year 2). Statistical repeated measures multivariate analysis of variance model results for velvetgrass cover and nontarget cover are presented in Table 1.

Although herbicide treatments significantly reduced cover of common velvetgrass for one year, it did not completely remove it. In addition, the one half reduction in cover caused by herbicide treatments was similar to the range in velvetgrass cover that occurred in control plots during this study (10 to $23 \%$ cover among years). Stated another way, declines in velvetgrass cover caused by herbicide treatment were similar to declines observed simply due to variable environmental conditions among years. Additionally, although the decrease in abundance was large in the first year, the treatment effect did not persist into the second year. Therefore, this one-time treatment application alone would not meet management objectives of controlling common velvetgrass, and additional treatment would be needed to maintain reduced cover levels. This is not an unexpected result, since 
glyphosate does not have residual soil activity, and we would expect the seed bank to be released following treatment (Froud-Williams et al. 1984).

The rapid recovery of common velvetgrass during posttreatment year 2 could be explained by heavy propagule pressure. Common velvetgrass is a prolific seeder (Peart 1989a) and an effective colonizer of bare soil. Seedlings are rapidly recruited posttreatment to glyphosateinduced bare patches (Peart 1989b), and seedling survivorship is high under favorable moisture availability such as occurs in meadows (Thomsen et al. 2006). Other studies have demonstrated that common velvetgrass can have little seedling recruitment yet successfully colonize bare soil vegetatively (Arnthórsdóttir 1994). We were unable to determine if increases in velvetgrass cover in postyear Year 2 were due to seedling establishment or vegetative growth.

The hand pulling treatment results corroborate our observations that this treatment is an ineffective control method at the infestation levels present in YOSE. This is consistent with another control study that demonstrated an increase in common velvetgrass abundance after a hand pulling treatment (Clark and Wilson 2001). This result is not unexpected as hand pulling root material generates substantial soil disturbance and such disturbance is known to promote seed germination (Froud-Williams et al. 1984). Other studies showed that common velvetgrass seedling establishment (Beddows 1961; Jesson et al. 2000) and cover (Buckland et al. 2001) increase with soil disturbance. These studies are all shorter-term than the expected persistence of the soil seed bank so it is possible that hand pulling could stimulate the germination of the seed bank and could facilitate depletion of the seed bank in the longer term with repeated treatments. This hypothesis remains to be tested, but even if repeated hand pulling proves to be effective, it would still be logistically intensive and only practical at small scales.

Nontarget Species Cover and Richness Response to Treatments. Treatments did not significantly affect nontarget species cover, but there was a significant year by treatment interaction (Table 1B). Unlike the common velvetgrass results, there were no obvious among-year treatment trends (Figure 1B). The mean nontarget cover across all treatments was $25.5 \% \pm 1.6$. In addition, treatments did not significantly affect species richness during the first two posttreatment years and there were no year by treatment interactions (Figure 2; Table 1C). Mean species richness across all treatments was $6.9 \pm 3.1$. Thus, there was no evidence of treatment effects on nontarget species or species richness.

These results help evaluate control efforts in the context of the management goal to support native plant assemblages. Although glyphosate is a broad-spectrum herbicide and could have negative effects on nontarget species, these

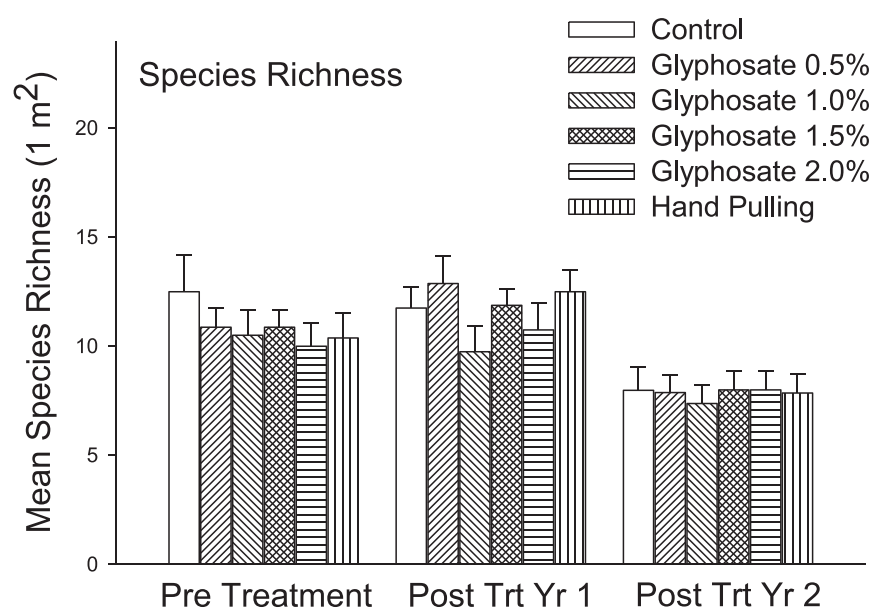

Figure 2. Mean species richness $( \pm \mathrm{SE})$ at the $1 \mathrm{~m}^{2}$ scale for each of the six treatments for 2010 (pretreatment), 2011 (posttreatment year 1) and 2012 (posttreatment year 2). Statistical repeated measures multivariate analysis of variance model results for species richness are presented in Table 1.

results demonstrate that our spot-spraying technique did not display any of these negative side-effects.

Variation Among Sites and Years. The vast majority of variation was not due to treatments which were the focus of this study, but instead due to the three sites used and the three years sampling was done (Table 1). Both common velvetgrass cover and nontarget species cover displayed significant main effects of site and year and the interaction between them (site by year). These results are not surprising considering the high potential for herbaceous plants to vary in cover and species richness among meadows and years of varying environmental characteristics. Details supporting this interpretation are presented in the following paragraphs. Because treatment effects did not vary among sites (no site by treatment interaction), we did not present graphics or other results for individual sites. In contrast, treatment effects did vary among years, so results were presented displaying interannual variation in treatments (Table 1). It should also be noted that much of the interannual variation in the treatment response reflected by the year by treatment interaction was due to the inclusion of the initial values (pretreatment) of the response variables along with their posttreatment years 1 and 2 values.

Recent fire history may explain some of the site variation we found in this study with respect to common velvetgrass cover, although studies show that fire has either a neutral effect on velvetgrass or a short-lived negative effect (Clark and Wilson 1998, 2001; Wilson and Clark 1997). Variation in species richness over years and by site may also be explained by fire as plant communities affected by fire initially experience an increase in richness, followed by a decrease (Shafi and Yarranton 1973). Species richness has 
also been shown to decrease after the first year of nonfire related succession (Tramer 1975). Due to varying canopy cover, sunlight is likely differentially available, which affects plant productivity and could also explain the variation in ground cover among sites. These three sites initially had varying levels of common velvetgrass dominance, as recorded as 2010 cover. This could be due to environmental factors or time since invasion, but the invasion history of these sites is unknown so we cannot determine which is most likely.

Precipitation amounts varied among years in concordance with observed response values. Precipitation was relatively high leading up to sampling during the pretreatment year (2010) and posttreatment year 1 (2011), whereas it was low prior to posttreatment year 2. However, late snow melt during pretreatment year 1 may have led to delayed vegetation phenology yielding lower cover of both target and nontarget plants at the time of the sampling. Thus, the resulting soil moisture conditions at time of sampling were likely high during 2010 when plant cover was highest, moderate during 2011 when cover was lower, and low during 2012 when cover as lowest.

The high magnitude of the site and year variation may have masked lesser-magnitude treatment effects, although the fact that none of the response variables displayed a significant site by year by treatment interaction suggests otherwise. Future studies of velvetgrass control strategies could benefit by including more replicate study sites to better account for variation among sites. Understanding variation among years, especially related to soil moisture levels, can best be evaluated by experimental manipulations of water.

\section{Acknowledgments}

Susan Jones, Athena Demetry, Robin White and three anonymous reviewers provided helpful comments on earlier versions of this paper. Any use of trade, product, or firm names is for descriptive purposes only and does not imply endorsement by the U.S. Government. This project was funded by the U.S. Geological Survey Park Oriented Biological Support program and the U.S. Geological Survey Invasive Species Management Program.

\section{Literature Cited}

Anderson SJ, Stone CP, Higashino PK (1992) Distribution and spread of alien plants in Kipahulu Valley, Haleakala National Park, above 2,300 ft. elevation. Pages 300-338 in Stone C, Smith C, Tunison J, eds. Alien Plant Invasions in Native Ecosystems of Hawai'i: Management and Research. Honolulu: University of Hawai'i Press

Arnthórsdóttir S (1994) Colonization of experimental patches in a mown grassland. Oikos 70:73-79

Bakker J, Dekker M, de Vries Y (1980) The effect of different management practices on a grassland community and the resulting fate of seedlings. Acta Bot Neerl 29:469-482

Bastow JL, Preisser EL, Strong DR (2008) Holcus lanatus invasion slows decomposition through its interaction with a macroinvertebrate detritivore, Porcellio scaber. Biol Invasions 10:191-199
Beddows A (1961) Holcus lanatus L. J Ecol 49:421-430

Buckland S, Thompson K, Hodgson J, Grime J (2001) Grassland invasions: effects of manipulations of climate and management. J Appl Ecol 38:301-309

Cal-IPC (2006) California Invasive Plant Inventory. Berkeley, CA: California Invasive Plant Council. Rep. Cal-IPC Publication 2006-02.

Clark DL, Wilson MV (1998) Fire effects on wetland prairie plant species. U.S. Report to the Fish and Wildlife Service, Western Oregon Refuges. Eugene, OR: Oregon State University

Clark DL, Wilson MV (2001) Fire, mowing, and hand-removal of woody species in restoring a native wetland prairie in the Willamette Valley of Oregon. Wetlands 21:135-144

D’Antonio CM, Berlow EL, Haubensak KL (2004) Invasive Exotic Plant Species in Sierra Nevada Ecoystems. USDA Forest Service Gen. Tech. Rep. PSW-GTR-193. Washington, DC: United States Department of Agriculture Forest Service. Pp 175-184

Debinski DM, Jakubauskas ME, Kindscher K (2000) Montane meadows as indicators of environmental change. Environ Monit Assess 64:213-225

Froud-Williams R, Chancellor R, Drennan D (1984) The effects of seed burial and soil disturbance on emergence and survival of arable weeds in relation to minimal cultivation. J Appl Ecol 21:629-641

Graber DM (1996) Status of terrestrial vertebrates. Pages 709-734 in Sierra Nevada Ecosystem Project: Final Report to Congress, Volume 2. Assessments and Scientific Basis for Management Options. Davis, CA: University of California, Centers for Water and Wildland Resources

Jesson L, Kelly D, Sparrow A (2000) The importance of dispersal, disturbance, and competition for exotic plant invasions in Arthur's Pass National Park, New Zealand. N Z J Bot 38:451-468

Kattelmann R, Embury M (1996) Riparian areas and wetlands Sierra Nevada Ecosystem Project: Final report to Congress, Volune 3. Assessments, Commissioned Reports, and Background Information. Davis, CA: University of California, Davis, Centers for Water and Wildland Resources

Klinger R, Underwood EC, Moore PE (2006) The role of environmental gradients in non-native plant invasion into burnt areas of Yosemite National Park, California. Divers Distrib 12: 139-156

Laufenberg SM, Sheley RL, Jacobs JS, Borkowski J (2005) Herbicide effects on density and biomass of Russian knapweed (Acroptilon repens) and associated plant species 1 . Weed Technol 19:62-72

Loope LL, Nagata RJ, Medeiros AC (1992) Alien plants in Haleakala National Park Pages 551-576 in Stone C, Smith C, Tunison J, eds. Alien Plant Invasions in Native Ecosystems of Hawai' i: Management and Research. Honolulu, Hawai'i: University of Hawai'i Press

Måren IE, Vandvik V, Ekelund K (2008) Restoration of brackeninvaded Calluna vulgaris heathlands: Effects on vegetation dynamics and non-target species. Biol Conserv 141:1032-1042

Michael E (1929) Brief survey of the plants of Yosemite National Park. Pages 162-171 in Michael E, ed. Yosemite Range-Naturalist Manual: Department of the Interior, National Park Service, Yosemite National Park.

Milligan AL, Putwain PD, Marrs RH (2003) A field assessment of the role of selective herbicides in the restoration of British moorland dominated by Molinia. Biol Conserv 109:369-379

Naramore RS (1949) Exotic grasses in Yosemite National Park. Yosemite Nature Notes 28:109-109

National Park Service (2010) Invasive Plant Management Plan Update Environmental Assessment. Yosemite National Park, CA: National Park Service.

National Park Service (2014) Invasive plant work plan for Yosemite National Park Yosemite National Park, CA: National Park Service NatureServe (2013) NatureServe Explorer: An Online Encyclopedia of Life. http://www.natureserve.org/explorer. Accessed August 22, 2013 
Peart, D (1989a) Species interactions in a successional grassland. I. Seed rain and seedling recruitment. J Ecol 77:236-251

Peart, D (1989b) Species interactions in a successional grassland. III. Effects of canopy gaps, gopher mounds and grazing on colonization. J Ecol 77:267-289

Rice PM, Toney, JC (1998) Exotic weed control treatments for conservation of fescue grassland in Montana. Biol Conserv 85:83-95

Rice PM, Toney JC, Bedunah DJ, Carlson CE (1997) Plant community diversity and growth form responses to herbicide applications for control of Centaurea maculosa. J Appl Ecol 34:1397-1412

SAS Institute (2008) User guide. Version 8.01. Cary, NC: SAS Institute. $515 \mathrm{p}$

Shafi M, Yarranton, G (1973) Diversity, floristic richness, and species evenness during a secondary (post-fire) succession. Ecology 54: 897-902

Thompson JD, Turkington, R (1988) The biology of Canadian weeds. 82. Holcus lanatus L. Can J Plant Sci 68:131-147

Thomsen MA, D'Antonio CM, Suttle KB, Sousa, WP (2006) Ecological resistance, seed density and their interactions determine patterns of invasion in a California coastal grassland. Ecol Lett 9:160-170
Tramer, EJ (1975) The regulation of plant species diversity on an early successional old-field. Ecology 56:905-914

Tyser RW, Asebrook JM, Potter RW, Kurth, LL (1998) Roadside revegetation in Glacier National Park, USA: effects of herbicide and seeding treatments. Restor Ecol 6:197-206

Underwood EC, Klinger R, Moore PE (2004) Predicting patterns of non-native plant invasions in Yosemite National Park, California, USA. Divers Distrib 10:447-459

Watt TA, Haggar R (1980) The effect of defoliation upon yield, flowering and vegetative spread of Holcus lanatus growing with and without Lolium perenne. Grass Forage Sci 35:227-234

Wilson MV, Clark, DL (1997) Final Report 1994-1997: Effects of fire, mowing, and mowing with herbicide on native prairie of Baskett Butte, Baskett Slough NWR: U.S. Fish and Wildlife Service, Western Oregon Refuges. Rep. Order No. 13590-6-0112

Received August 21, 2014, and approved March 28, 2015.

Associate Editor for this paper: Jane M. Mangold, Montana State University. 